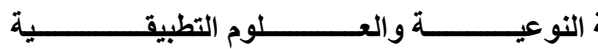

بية للتربيـ

لة العلم

المج

The Scientific Journal of Specific Education and Applied Sciences

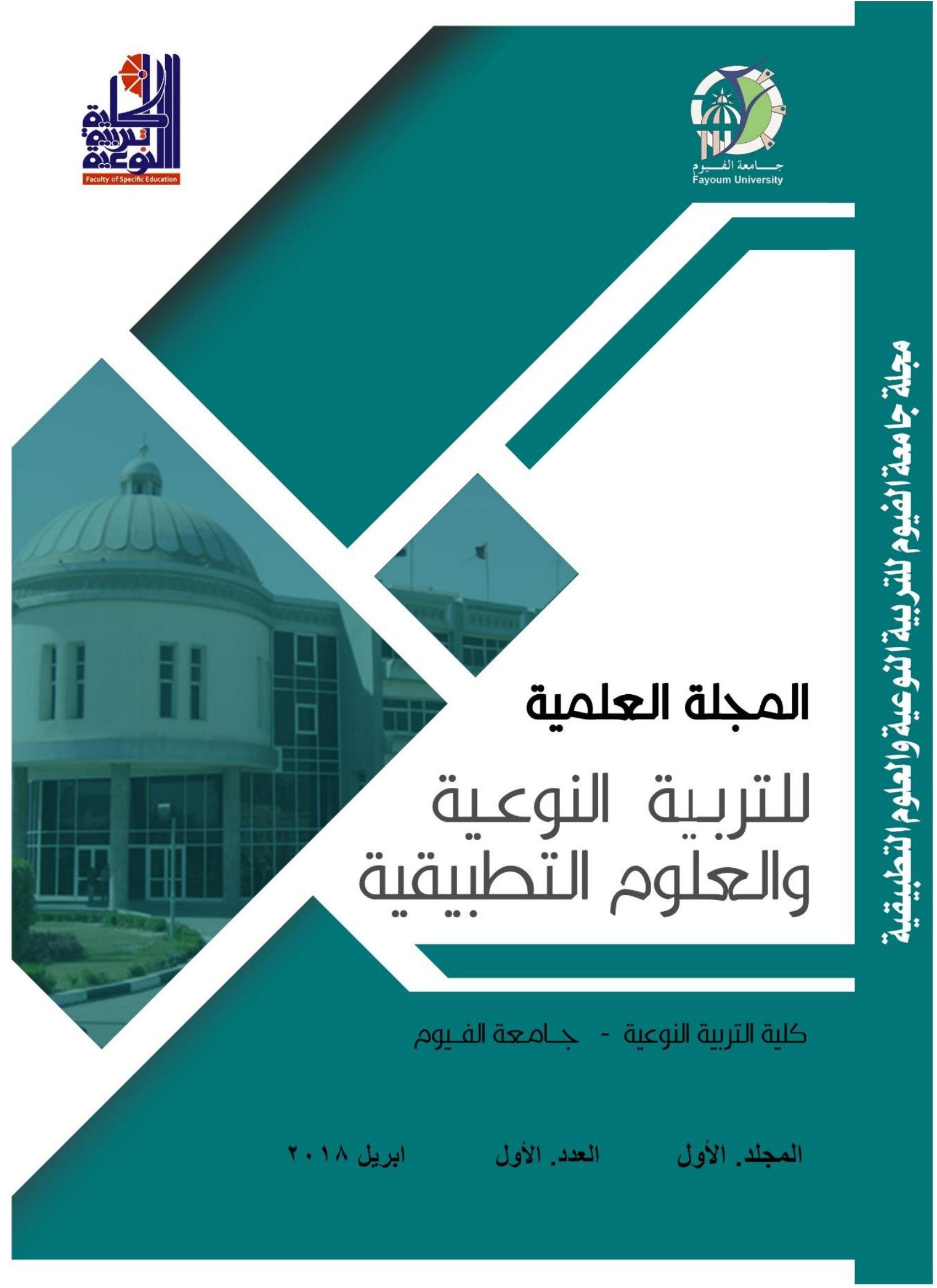




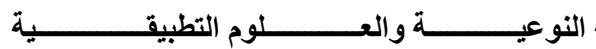

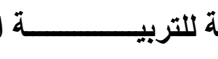

The Scientific Journal of Specific Education and Applied Sciences

\section{Evaluation the Protective Effect of Moringa Oleifera Seeds Oil \\ Against Diabetic Nephropathy in Male Rats. Soha M. Yousef}

Nutrition \& Food Sciences, Home Economics Department, Faculty of Specific Education, Fayoum University, Egypt.

Abstract:This study was carried out to investigate the protective effect of Moringa Oleifera seeds oil on diabetic nephropathy in male rats. Forty adult male sprague dawley rats were divided into two main groups. The first main group: was divided into two subgroups (10 rats each). (G1) was fed standard diet only as a negative control group and (G2) was fed standard diet containing Moringa seeds oil $(1.8 \mathrm{mg} / \mathrm{kg})$. The second main group: intravenously injected by a single dose of streptozotocin (60 $\mathrm{mg} / \mathrm{kg}$ ), the diabetic rats were divided into two subgroups (10 rats each). (G3) diabetic rats were fed only standard diet and (G4) diabetic rats were fed on standard diet containing Moringa seeds oil $(1.8 \mathrm{mg} / \mathrm{kg})$. The study was conducted for four weeks. The obtained results showed that fasting blood sugar was increased in (G3) as a result of diabetes. The diabetic rats (G3) recorded significantly elevation in serum urea nitrogen, creatinine and uric acid as a sign of diabetic nephropathy. Moreover serum sodium levels was elevated and potassium levels was reduced in (G3). Serum total protein and albumin levels were significantly decreased in (G3) compared with (G1). Diabetic rats (G3) exhibited a significantly reduction in glutathione level in both serum and kidney tissue. Treating the diabetic rats with Moringa seeds oil (G4) ameliorated the levels of all these parameters approaching the negative control values. The results suggest that Moringa oleifera seeds oil has ability to protect against diabetic nephropathy due to its content of phytochemicals. MO almost restored the diabetic rats to the normal healthy status. 


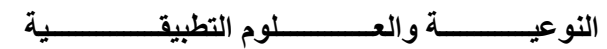

烈

The Scientific Journal of Specific Education and Applied Sciences

Keywords: Moringa oleifera seeds oil; Diabetic nephropathy; phytochemicals.

\section{Introduction:}

Diabetes mellitus is a chronic metabolic disorder characterized by disturbance in glucose metabolism leading to a state of hyperglycemia, which is associated with complications in the long term. Chronic complications occur over years of hyperglycemia include macrovascular complications (coronary heart disease, peripheral vascular disease, stroke) and microvascular complications (retinopathy, neuropathy, nephropathy) (Catharine et al., 2014). World Health Organization estimated that diabetes mellitus will be the seventh main reason of death in 2030 . Worldwide, the number of people with diabetes has increased from 108 million to 422 million between 1980 and 2014 (World Health Organization, 2016). More than 39 million people have diabetes in the Middle East and North Africa Region. In Egypt, there were 8 million cases of diabetes in 2017(International Diabetes Federation, 2018).

One third or more of the diabetes mellitus patients develop diabetic nephropathy (DN) with progressive deterioration of kidney functions and structure. (DN) is the leading cause of end stage renal disease (ESRD) worldwide (Enyioma and Abdu, 2005). Diabetic nephropathy characterized by persistent albuminuria, progressive decline in glomerular filtration rate (GFR) and raised arterial blood pressure (Efundem et al., 2017).

Moringa Oleifera Lam (belonging to Moringaceae family) is a highly valued plant, distributed in the tropics and subtropics countries. Every part of Moringa Oleifera is a storehouse of important nutrients. Different parts of this plant contain important minerals and are a good source of protein, amino acids, vitamins, beta-carotene, and various phenolic (Anwar et al., 2007). 


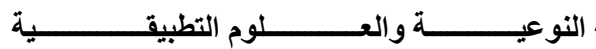
㪿

The leaves of Moringa Oleifera are rich in mineral like calcium, potassium, zinc, magnesium, and iron, vitamins like beta-carotene, B, C, D and E, Phytochemicals such as tannins, sterols, and flavonoids (Mbikay, 2012). The Researches show that immature pods of Moringa Oleifera contain 20.66\%protein and around $46.78 \%$ fiber (Sanchez et al., 2010). Moringa Oleifera seed has shown the presence of some bioactive compounds. Seed extracts have antimicrobial properties that inhibit bacterial growth (Guevara et al., 1999). Moringa seeds are used to extract oil called the Ben oil. This oil is rich in oleic acid, tocopherols and sterols. The oil can be used as a substitute for olive oil (Fahey, 2005). The researches show that Moringa seed oil contains around 76\% PUF (linoleic acid, linolenic acid and oleic acid), making it ideal for use as a substitute for olive oil (Lalas and Tsaknis, 2002). Moringa Oleifera oil has yellow colour with nutty flavour and fatty acids composition suggests that is highly suitable for both edible and non-edible applications. It is extremely resistant to oxidation which can be used as an antioxidant (Nadeem and Imran, 2016).

Several studies have shown that Moringa can act as an antidiabetic agent. A study has shown that aqueous extracts of MO can treat streptozotocin induced diabetes in rats (Divi et al., 2012). Past investigations have demonstrated that aqueous methanolic and ethanolic extracts of MO leaves have an extensive variety of biological activities such as antioxidant, tissue protective (liver, kidneys, heart, testes, and lungs), antihypertensive, and immunomodulatory actions in vivo (Stohs and Hartman, 2015).

Moringa oleifera leaves shown to be beneficial in many chronic diseases including hypercholesterolemia, diabetes, insulin resistance, cancer, non-alcoholic liver disease and overall inflammation (Marcela et al., 2017). The antioxidant and antidiabetic effects of Moringa Oleifera leaves indicated potential 


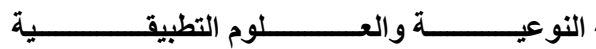
型

benefits as a potent antidiabetic in streptozotocin induced diabetic in rats (Yassa and Tohamy, 2014).

In another study, the fasting blood glucose dropped in STZ induced diabetes rats fed with Moringa seed powder (Abdulrahman and Haddad, 2015). Moreover, when the rats treated with moringa seed powder $(500 \mathrm{mg} / \mathrm{kg} \mathrm{b.w})$ the antioxidant enzymes elevated in the serum. This shows that the antioxidants in Moringa can minimize the reactive oxygen species (ROS) caused in the Beta-cells due to the STZ induction (Mbikay, 2012).

This study is carrying out to investigate the protective effect of Moringa Oleifera seeds oil on diabetic nephropathy in male rats.

\section{Materials and Methods:}

Materials:

- Forty adult male albino rats of Spague Dawley Strain weighing (150-200 g) were purchased from laboratory of animals, The National Center for Researches, Cairo, Egypt.

- Streptozotocin (STZ) was obtained from (Sigma- Aldrich), purchased from The Egyptian International Center for Import, Cairo, Egypt.

- Diagnostic kits for biochemical analysis produced by Spectrum (Egyptian Company for Biotechnology), purchased from Gama Co., Cairo, Egypt.

\section{Methods:}

\section{Preparation of diet:}

Standard diet was prepared according to (Philp et al., 1993). Standard diet comprised of casein $(140.0 \mathrm{~g} / \mathrm{kg}$ diet $)$, cornstarch $(465.69 \mathrm{~g} / \mathrm{kg} \mathrm{diet})$, sucrose $(100.0 \mathrm{~g} / \mathrm{kg}$ diet $)$, cellulose $(50.0 \mathrm{~g} / \mathrm{kg}$ diet), corn oil (40.0 g/ $\mathrm{kg} \mathrm{diet),} \mathrm{mineral} \mathrm{mix}(35.0 \mathrm{~g} / \mathrm{kg}$ diet $)$, vitamin mix $(10.0 \mathrm{~g} / \mathrm{kg} \mathrm{diet})$, DL-methionine $(3.0 \mathrm{~g} / \mathrm{kg}$ diet $)$ and choline chloride $(2.5 \mathrm{~g} / \mathrm{kg}$ diet $)$. 


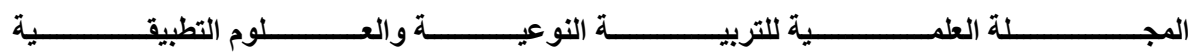

The Scientific Journal of Specific Education and Applied Sciences

\section{Experimental design:}

All rats allowed free access to water and standard diet for four days as an adaptation period before starting the experiment. After the acclimation period, all rats were individually weighed and housed separately in stainless steel cages. The rats were divided into two main groups as the following:

The first main group: was divided into two subgroups (10 rats each). (G1) was fed standard diet only as a negative control group and (G2) was fed standard diet containing Moringa seeds oil (1.8 $\mathrm{mg} / \mathrm{kg}$ b.w.) (Sunny et al., 2017).

The second main group: the rats were fasting overnight, then intravenously injected with freshly prepared streptozotocin (STZ; $60 \mathrm{mg} / \mathrm{kg} \mathrm{b}$. w. in $0.1 \mathrm{~mol} / \mathrm{L}$ citrate buffer, $\mathrm{pH} \mathrm{4.5)}$ (Jaiswal et al., 2013). Rats were considered diabetic when fasting blood glucose levels were $\geq 200 \mathrm{mg} / \mathrm{dl}$. Only diabetic rats were included in the study. The diabetic rats were divided into two subgroups (10 rats each). (G3) diabetic rats were fed only standard diet and (G4) diabetic rats were fed on standard diet containing Moringa seeds oil (1.8 mg/kg b.w.) (Sunny et al., 2017).The study was conducted for four weeks.

At the end of the experiment, all rats were sacrificed under anaesthesia. Blood samples of rats were centrifuged at 3000 r.p.m. for 15 minutes. Serum samples were carefully separated and stored at $-20^{\circ} \mathrm{c}$ for biochemical analysis. After sacrificed of rats and blood sampling, the heart, liver and two kidneys were removed, rinsed in saline $(0.9 \% \mathrm{Na} \mathrm{Cl})$ and weighed. The relative weigh of organs were estimated by comparing the organ weight to the total body weight of each rat. Relative organ weight $=$ organ weight $(\mathrm{g}) /$ total body weight $(\mathrm{g}) \times 100$ 


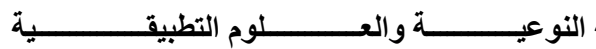

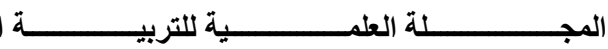

The Scientific Journal of Specific Education and Applied Sciences

\section{Biological Evaluations:}

- Food intake: The total diet consumed during the period of the experiment was calculated every week.

- Body weight gain: Each rat was weighed every week.

- Food efficiency ratio: (FER) was calculated according to (Chapman et al., 1959).

\section{Biochemical parameters:}

- Fasting blood sugar determined using the method of (Bergmeyer and Bernt, 1974).

- Renal functions:

- Serum Urea Nitrogen, Creatinine and Uric Acid were determined by the methods of (Tietz, 1990 and Tietz, 1986).

- Serum Sodium and Potassium ions were estimated using the methods of (Trinder, 1951 and Sunderman and Sunderman, 1958)

- Serum Total Protein and Albumin were determined using the methods of (Tietz, 1994 and Tietz, 1990).

- Antioxidant levels:

- Reduced Glutathione (GSH) in the serum and in the tissue of kidney were estimated using the methods of (Beutler et al., 1963).

\section{Statistical analysis:}

The results were analyzed statistically using SPSS program. Ttest and one way analysis of variance (ANOVA) were applied to compare the means values between groups (Waller and Duncan, 1969).

\section{Results and Discussion:}

Data summarized in table (1) showed that the diabetic rats (G3) exhibited significant decrease in food intake, body weight gain and food efficiency ratio at $(\mathrm{p}<0.01)$ compared with negative control group. However diabetic rats which fed on standard diet containing 


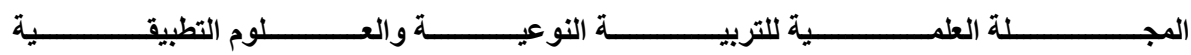

The Scientific Journal of Specific Education and Applied Sciences

Moringa seeds oil (G4) showed significantly increased $(\mathrm{p}<0.01)$ of these parameters.

The decrease in the body weight of the diabetic rats is possibly due to dehydration and the catabolism of fats and proteins (Hakim et al., 1997). (Rajkumar et al., 1991) reported that increased catabolic reactions leading to muscle wasting and might also contribute to the reduced weight gain by diabetic rats. Moreover, (Snehal et al., 2017) demonstrated that STZ-induced diabetes is associated with significant decreased in the body weight due to hyperglycemia, hypoinsulinemia, increased muscle wasting and loss of tissue proteins.

Table (1): Effect of Moringa Oleifera seeds oil on food intake, body weight gain and food efficiency ratio in diabetic nephropathy rats.

\begin{tabular}{|c|c|c|c|c|}
\hline Parameters & $\begin{array}{c}\text { G1 } \\
\text { negative control }\end{array}$ & $\begin{array}{c}\text { G2 } \\
\text { negative control } \\
+ \text { Moringa } \\
\end{array}$ & $\begin{array}{c}\text { G3 } \\
\text { Diabetic rats }\end{array}$ & $\begin{array}{c}\text { G4 } \\
\text { Diabetic rats } \\
+ \text { Moringa } \\
\end{array}$ \\
\hline $\begin{array}{l}\text { Food Intake } \\
\text { (g/day) }\end{array}$ & $14.52 \pm 0.12^{\mathrm{a}}$ & $14.60 \pm 0.20^{\mathrm{a}}$ & $13.66 \pm 0.19^{b}$ & $13.54 \pm 0.15^{b}$ \\
\hline p.value & - & - & $* *$ & $* *$ \\
\hline $\begin{array}{l}\text { Body Weight Gain } \\
\text { (g/28 day) }\end{array}$ & $23.75 \pm 0.30^{\mathrm{a}}$ & $23.40 \pm 0.24^{\mathrm{a}}$ & $-32.23 \pm 1.18^{c}$ & $14.15 \pm .092^{b}$ \\
\hline p.value & - & - & $* *$ & $* *$ \\
\hline $\begin{array}{c}\text { Food Efficiency Ratio } \\
\text { (g/day) }\end{array}$ & $0.058 \pm 0.003^{\mathrm{a}}$ & $0.057 \pm 0.002^{\mathrm{a}}$ & $-0.084 \pm 0.003^{c}$ & $0.037 \pm 0.002^{b}$ \\
\hline p.value & - & - & $* *$ & $* *$ \\
\hline
\end{tabular}

- Values are represented as mean $\pm \mathrm{SD}$, values are statistically significant at $* * \mathrm{p}<0.01$

- No significant difference between the values had the same letter in each row.

The obtained result in table (2) indicated that relative weight of liver, kidneys and heart in diabetic rats (G3) significantly increased at $(\mathrm{p}<0.01)$ compared with negative control group $(\mathrm{G} 1)$. Rats treated with Moringa seeds oil (G4) showed significantly reduction $(\mathrm{p}<0.01)$ in the relative weight of these organs approaching negative control group $(\mathrm{G} 1)$. 


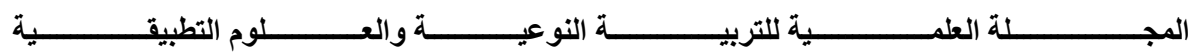

The Scientific Journal of Specific Education and Applied Sciences

The results was agree with (Ahmed, 2012) who showed that the final kidney/ body weight ratios of untreated diabetic animals were significantly higher than those of control animals. Furthermore, (Snehal et al., 2017) demonstrated that increase in the kidney weight (hypertrophy) in proportion to the body weight was observed in STZ-induced diabetes rats.

\section{Table (2): Effect of Moringa Oleifera seeds oil on the relative organs weight in diabetic nephropathy rats.}

\begin{tabular}{|c|c|c|c|c|}
\hline Parameters & $\begin{array}{c}\text { G1 } \\
\text { negative } \\
\text { control }\end{array}$ & $\begin{array}{c}\text { G2 } \\
\text { negative } \\
\text { control } \\
+ \text { Moringa } \\
\end{array}$ & $\begin{array}{c}\text { G3 } \\
\text { Diabetic rats }\end{array}$ & $\begin{array}{c}\text { G4 } \\
\text { Diabetic rats } \\
+ \text { Moringa }\end{array}$ \\
\hline Relative liver weight \% & $3.37 \pm 0.11^{\mathrm{c}}$ & $3.42 \pm 0.07^{\mathrm{c}}$ & $5.54 \pm 0.16^{\mathrm{a}}$ & $3.70 \pm 0.12^{\mathrm{b}}$ \\
\hline p.value & - & - & $* *$ & $* *$ \\
\hline Relative kidneys weight \% & $0.61 \pm 0.04^{\mathrm{c}}$ & $0.58 \pm 0.03^{\mathrm{c}}$ & $0.955 \pm 0.05^{\mathrm{a}}$ & $0.603 \pm 0.021^{\mathrm{b}}$ \\
\hline p.value & - & 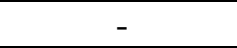 & $* *$ & $* *$ \\
\hline Relative heart weight $\%$ & $0.291 \pm 0.01^{\mathrm{b}}$ & $0.289 \pm 0.02^{\mathrm{b}}$ & $0.320 \pm 0.04^{\mathrm{a}}$ & $0.290 \pm 0.01^{\mathrm{b}}$ \\
\hline p.value & - & -2 & $* *$ & $* *$ \\
\hline
\end{tabular}

- Values are represented as mean $\pm \mathrm{SD}$, values are statistically significant at $* * \mathrm{p}<0.01$

- No significant difference between the values had the same letter in each row.

Data presented in table (3) showed that serum glucose level was significantly increased $(\mathrm{p}<0.001)$ in STZ diabetic rats $(\mathrm{G} 3)$ comparing with negative control group (G1). However treatment of rats with Moringa seeds oil (G4) showed significantly reduction $(\mathrm{p}<0.01)$ in serum glucose level comparing with diabetic rats (G3).

\section{Table (3): Effect of Moringa Oleifera seeds oil on Fasting blood}

Sugar in diabetic nephropathy rats.

\begin{tabular}{|c|c|c|c|c|}
\hline Parameters & $\begin{array}{c}\text { G1 } \\
\text { negative } \\
\text { control }\end{array}$ & $\begin{array}{c}\text { G2 } \\
\text { negative } \\
\text { control } \\
+ \text { Moringa }\end{array}$ & $\begin{array}{c}\text { G3 } \\
\text { Diabetic rats }\end{array}$ & $\begin{array}{c}\text { G4 } \\
\text { Diabetic rats } \\
\text { + Moringa }\end{array}$ \\
\hline
\end{tabular}




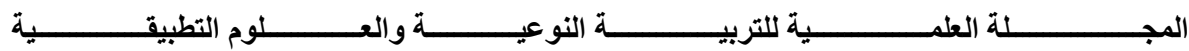

The Scientific Journal of Specific Education and Applied Sciences

\begin{tabular}{|c|c|c|c|c|}
\hline $\begin{array}{c}\text { Fasting blood sugar } \\
(\mathrm{mg} / \mathrm{dl})\end{array}$ & $85.82 \pm 2.84^{\mathrm{c}}$ & $87.41 \pm 2.71^{\mathrm{c}}$ & $265.52 \pm 2.14^{\mathrm{a}}$ & $150.46 \pm 2.63^{\mathrm{b}}$ \\
\hline p.value & - & - & $* *$ & $* *$ \\
\hline
\end{tabular}

- Values are represented as mean $\pm \mathrm{SD}$, values are statistically significant at $* * \mathrm{p}<0.01$

- No significant difference between the values had the same letter in each row.

Diabetic rats injected with STZ showed increased serum glucose levels, which is indicative of hyperglycemia. These data are consistent with (Brenna et al., 2003) who demonstrated that Streptozotocin is a potent cytotoxic and causes acute diabetes. Furthermore, (Szkudelski, 2001) demonstrated that Streptozotocinis used to induce insulin dependent diabetes mellitus and noninsulin dependent diabetes mellitus. Rats treated with STZ manifested hyperglycemia, an impaired response to the glucose tolerance test.

Treatment diabetic rats with Moringa seeds oil showed significantly reduction in serum glucose level comparing with diabetic rats which indicates that Moringa seeds oil is able to elevate insulin ability to decrease serum glucose and its antidiabetic effect. This result is in the line with (Olayaki et al., 2015) that revealed that administration of methanolic extract of Moringa oleifera leaves ameliorated glucose tolerance, and increased serum insulin. Furthermore, (Yassa and Tohamy, 2014) reported that Moringa oleifera leaves treatment significantly improved the altered fasting plasma glucose compared to control levels.

The obtained results in table (4) illustrated that diabetic rats (G3) recorded significantly elevation in serum urea nitrogen, creatinine and uric acid comparing with negative control group (G1). While treatment of rats with Moringa seeds oil (G4) showed significantly higher in serum urea nitrogen, creatinine and uric acid in comparing with negative control group (G1), but showed 


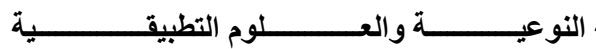

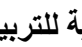

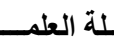

The Scientific Journal of Specific Education and Applied Sciences

significantly lower of these parameters in compared with diabetic rats $(\mathrm{G} 3)$.

In this respect (Rochette et al., 2014) demonstrated that the increasing of blood glucose induced oxidative stress resulting in an increased production of oxygenated free radicals and decreased antioxidant enzyme activities. This may result in intracellular structure modification and ultimately affect the normal cellular function, leading to pathogenesis and development of diabetic complications. Furthermore, (Prabhu et al., 2008) showed that free radical in diabetes is one of the leading reasons for kidney dysfunction associated with increasing in levels of urea nitrogen and creatinine due to persistent hyperglycemia.

Data summarized in table (4) showed in diabetic rats (G3) a significant elevation in serum sodium levels and significant reduction in potassium levels when compared with negative control group (G1). Treating diabetic rats with Moringa seeds oil (G4) showed significantly ameliorated in levels of serum sodium and potassium compared with diabetic rats (G3). (Shenqi et al., 2013) demonstrated that disturbances in the levels of some electrolytes are associated with diabetes mellitus.

Table (4) presented that serum total protein and albumin levels were significantly decreased $(\mathrm{p}<0.01)$ in diabetic rats $(\mathrm{G} 3)$ compared with negative control group (G1). Serum total protein and albumin levels significantly increased in Moringa seeds oil treated rats (G4) compared to untreated diabetic rats (G3). In diabetic, it was observed a loss in blood proteins, when excessive; change the normal filtering mechanism of the renal resulting in the accumulation of toxic wastes. Albumin serves as transport protein and biomarkers in the disease state (Santos et al., 2012). 


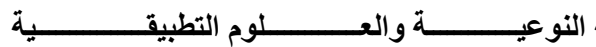

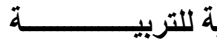

لاة العلمـــ

The Scientific Journal of Specific Education and Applied Sciences

\section{Table (4): Effect of Moringa Oleifera seeds oil on Serum Urea Nitrogen, Creatinine, Uric Acid, Sodium, Potassium, Total \\ Protein and Albumin in diabetic nephropathy rats.}

\begin{tabular}{|c|c|c|c|c|}
\hline Parameters & $\begin{array}{c}\text { G1 } \\
\text { negative } \\
\text { control }\end{array}$ & $\begin{array}{c}\text { G2 } \\
\text { negative } \\
\text { control } \\
+ \text { Moringa } \\
\end{array}$ & $\begin{array}{c}\text { G3 } \\
\text { Diabetic rats }\end{array}$ & $\begin{array}{c}\text { G4 } \\
\text { Diabetic rats } \\
\text { + Moringa }\end{array}$ \\
\hline $\begin{array}{l}\text { Urea Nitrogen } \\
\qquad(\mathrm{mg} / \mathrm{dl})\end{array}$ & $26.11 \pm 0.98^{c}$ & $25.81 \pm 0.87^{c}$ & $69.78 \pm 89^{a}$ & $31.71 \pm 1.17^{b}$ \\
\hline p.value & - & - & $* *$ & $* *$ \\
\hline $\begin{array}{l}\text { Creatinine } \\
(\mathrm{mg} / \mathrm{dl})\end{array}$ & $0.65 \pm .05^{\mathrm{c}}$ & $0.64 \pm 0.04^{\mathrm{c}}$ & $2.78 \pm 0.15^{\mathrm{a}}$ & $0.91 \pm 0.04^{b}$ \\
\hline p.value & - & - & $* *$ & $* *$ \\
\hline $\begin{array}{l}\text { Uric Acid } \\
(\mathrm{mg} / \mathrm{dl})\end{array}$ & $1.12 \pm 0.07^{\mathrm{c}}$ & $1.49 \pm 0.04^{\mathrm{c}}$ & $2.87 \pm 0.06^{\mathrm{a}}$ & $1.5 \pm .013^{b}$ \\
\hline p.value & - & - & $* *$ & $* *$ \\
\hline $\begin{array}{l}\text { Sodium } \\
(\mathrm{mmol} / \mathrm{L})\end{array}$ & $133.12 \pm 0.73^{c}$ & $134.21 \pm 0.62^{\mathrm{c}}$ & $150.91 \pm 0.8^{a}$ & $136.17 \pm 0.70^{b}$ \\
\hline p.value & - & - & $* *$ & $* *$ \\
\hline $\begin{array}{c}\text { Potassium } \\
(\mathrm{mmol} / \mathrm{L})\end{array}$ & $4.42 \pm 0.03^{\mathrm{a}}$ & $4.50 \pm 0.02^{\mathrm{a}}$ & $3.16 \pm 0.04^{c}$ & $4.10 \pm 0.06^{b}$ \\
\hline p.value & - & - & $* *$ & $* *$ \\
\hline $\begin{array}{l}\text { Total Protein } \\
(\mathrm{g} / \mathrm{dl})\end{array}$ & $7.57 \pm 0.11^{\mathrm{a}}$ & $7.50 \pm 010^{\mathrm{a}}$ & $4.45 \pm 0.15^{c}$ & $6.25 \pm 0.14^{b}$ \\
\hline p.value & - & - & $* *$ & $* *$ \\
\hline $\begin{array}{l}\text { Albumin } \\
(\mathrm{g} / \mathrm{dl})\end{array}$ & $3.87 \pm 0.17^{\mathrm{a}}$ & $3.90 \pm 0.13^{a}$ & $1.75 \pm 0.13^{c}$ & $2.91 \pm 0.18^{b}$ \\
\hline p.value & - & - & $* *$ & ** \\
\hline
\end{tabular}

- Values are represented as mean $\pm \mathrm{SD}$, values are statistically significant at $* * \mathrm{p}<$ 0.01

- No significant difference between the values had the same letter in each row.

The obtained results are confirmed with (Afshari et al., 2007, Ahmed, 2012and Snehal et al., 2017) who showed that development of diabetic nephropathy was determined by significant reduction in serum albumin and significant elevations of serum urea nitrogen, uric acid and creatinine in STZ diabetic rats. Study by (Pooja et al., 2017) shows highly significant 


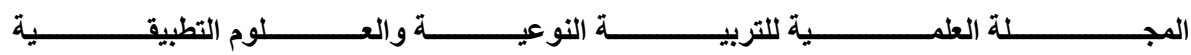

The Scientific Journal of Specific Education and Applied Sciences

changes in the levels of BUN, serum creatinine, uric acid, sodium, potassium in diabetic patients indicating kidney damage.

Treating diabetic rats with Moringa seeds oil improved the levels of all these parameters compared with untreated diabetic rats. These results are consistent with (Elizabeth et al., 2017) who suggested that treatment with Moringa oleifera has ability to ameliorate the renal functions. This demonstrates the protective effect of Moringa against diabetic renal damage, which is caused by its antioxidant properties (Muobarak, 2016).

Furthermore (Radhey, 2012) indicated that Moringa oleifera treatment significantly elevated the level of albumin in serum of STZ diabetic rats. It may be due to a reduction albumin affinity towards glucose. (Govindarajan et al., 2016) proved that bioactive ingredients and essential trace elements in Moringa oleifera help to protective the renal from damage. (Al Said et al., 2012) indicated that the possible mechanism in protective activity of Moringa oleifera seeds oil may be due to free radical scavenging potential caused by the presence of antioxidant components in the oil.

Table (5): Effect of Moringa Oleifera seeds oil on Glutathione (GSH) in serum and kidney tissue in diabetic nephropathy rats.

\begin{tabular}{|c|c|c|c|c|}
\hline Parameters & $\begin{array}{c}\text { G1 } \\
\text { negative } \\
\text { control }\end{array}$ & $\begin{array}{c}\text { G2 } \\
\text { negative } \\
\text { control } \\
\text { Moringa }\end{array}$ & $\begin{array}{c}\text { G3 } \\
\text { Diabetic rats }\end{array}$ & $\begin{array}{c}\text { G4 } \\
\text { Diabetic rats } \\
\text { + Moringa }\end{array}$ \\
\hline $\begin{array}{c}\text { Glutathione / serum } \\
\text { U/mL }\end{array}$ & $25.19 \pm 0.53^{\mathrm{a}}$ & $26.21 \pm 0.21^{\mathrm{a}}$ & $8.81 \pm 0.20^{\mathrm{c}}$ & $16.98 \pm 0.55^{\mathrm{b}}$ \\
\hline $\mathrm{p} . \mathrm{value}$ & - & - & $* *$ & $* *$ \\
\hline $\begin{array}{c}\text { Glutathione/ kidney tissue } \\
\text { U/g }\end{array}$ & $62.10 \pm 0.84^{\mathrm{a}}$ & $63.50 \pm 1.04^{\mathrm{a}}$ & $25.60 \pm 0.57^{\mathrm{c}}$ & $51.11 \pm 1.05^{\mathrm{b}}$ \\
\hline $\mathrm{p}$. value & - & - & $* *$ & $* *$ \\
\hline
\end{tabular}

- Values are represented as mean $\pm \mathrm{SD}$, values are statistically significant at $* * \mathrm{p}<$ 0.01 


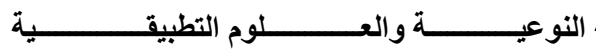

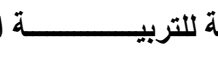

The Scientific Journal of Specific Education and Applied Sciences

- No significant difference between the values had the same letter in each row.

Data summarizes in table (5) showed that diabetic rats (G3) exhibited a significantly reduction in glutathione level in both serum and kidney tissue compared with negative control group (G1). While treatment of rats with Moringa seeds oil (G4) showed significantly increased in glutathione level in serum and kidney tissue.

Glutathione is a powerful antioxidant since it possesses a property in scavenging hydroxyl radical. The obtained results are consistent with (Elizabeth et al., 2017) demonstrated that GSH were ameliorate in all groups of diabetic rats treated with Moringa oleifera. Suggesting that MO has property to scavenge and neutralize STZ induced oxidative stress. The results also agree with (Radhey, 2012) who cleared that glutathione is a main factor in antioxidant system. GSH has the ability to defense against cytotoxic and free radicals. Treated diabetic rats with Moringa oleifera showed an elevation in glutathione levels. Reduced the reactive oxygen species production, may be the reason.

Furthermore, (Ghiridhari et al., 2011) confirmed that the therapeutic effect of Moringa oleifera seeds due to the presence of active ingredients. Flavonoids and phenolic are the components responsible for the activity of antioxidant in Moringa oleifera seeds. Moreover (Yassa and Tohamy, 2014) reported that there are three types of phytochemicals in Moringa oleifera have therapeutic benefits. They are gluosinolates, flavonoids and phenolic acids. (Lako et al., 2007) elucidated that the phytochemicals in Moringa oleifera are responsible for its ability to be antioxidant, hypotensive, hypoglycemic, anticancer and antiinflammatory.

\section{Conclusion:}




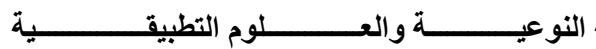
型

Based on experimental evidence of the study, the results suggest that Moringa oleifera seeds oil has ability to protect against diabetic nephropathy due to its content of phytochemicals. MO almost restored the diabetic rats to the normal healthy status. It was also able to improve antioxidant status, has potential to be used as an antidiabetic agent in the treatment and management of diabetes.

\section{References}

\section{Ahmed, A. R.S. (2012):}

Ferulsinaic Acid Modulates SOD, GSH, and Antioxidant Enzymes in Diabetic Kidney. Evidence-Based Complementary and Alternative Medicine. 2012: 9-18.

Afshari, A. T.; Shirpoor, A. and Farshid, A. (2007):

The effect of ginger on diabetic nephropathy, plasma antioxidant capacity and lipid peroxidation in rats. Food Chemistry. 101(1):148-153.

\section{Abdulrahman, L.A. and Haddad, A. (2015):} The antidiabetic effect of low doses of Moringa oleifera Lam. seeds on streptozotocin induced diabetes and diabetic nephropathy in male rats. Biomed. Res. Int. 2015: 1-13.

Al Said, M.S. ; Mothana, R.A.; Al Yahya, M.A.; Al Blowi, A.S.; Al Sohaibani, M.; Ahmed, A.F.; and Rafatullah, S.(2012):

Edible oils for liver protection: hepatoprotective potentiality of Moringa oleifera seed oil against chemical-induced hepatitis in rats. J Food Sci. 77(7): 124-30.

Anwar, F.; Latif, S.; Ashraf, M. and Gilani, AH. (2007):

Moringa oleifera: a food plant with multiple medicinal uses. Phytother Res. 21(1):17-25.

\section{Bergmeyer, H.U. and Bernt, E. (1974):}

Methods of enzymatic analysis. New York. Academic Press. $2^{\text {nd }}$ ed. $1205-1212$. 


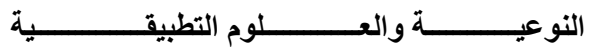
望

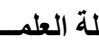

The Scientific Journal of Specific Education and Applied Sciences

Beutler, E.; Duron, O. and Kelly, BM. (1963):

Improved method for the determination of blood glutathione.

J. Lab. Clin.Med. 61: 882-8.

Brenna O, Qvigstad G, Brenna E, Waldu HL.

Cytotoxicity of streptozotocin on neuroendocrine cells

of the pancreas and the gut. Dig Dis Sci. 2003; 48: 90610.

Brenna, O.; Qvigstad, G.; Brenna, E. and Waldu, HL. (2003):

Cytotoxicity of Streptozotocin on neuroendocrine cells of the pancreas and the gut. Dig. Dis. Sci. 48: 906-10.

Catharine Ross, A.; Benjamin caballero; Robert, j. Cousins; Katherine, L. Tucker and Thomas, R. Ziegler (2014):

Modern nutrition in health and disease. 11th Edition: 808-813. Wolters Kluwer. Lippincott Williams \& Wilkins.

Chapman, D.G.; Castillo, R. and Campbell, J.A. (1959):

Evaluation of protein in food. I.A. method for the determination of protein efficiency ratio. Can. j. Biochem. Phsiol. 37 (5): 679-386.

Divi, S.M.; Bellamkonda, R. and Dasireddy, S.K. (2012):

Evaluation of antidiabetic and antihyperlipedemic potential of aqueous extract of Moringa oleiferain in fructose fed insulin resistant and STZ induced diabetic wistar rats: acomparative study, Asian J. Pharm. Clin. Res. 5: 67-72.

Efundem, N.T.; Assob, J.C.N.; Feteh, V.F. and Choukem, S.P. (2017):

Prevalence and associations of micro albuminuria in proteinuria-negative patients with type 2 diabetes in two regional hospitals in Cameroon: a cross-sectional study. BMC Res Notes. 10: 477-490.

Elizabeth, I. O.; Yapo, G. A. and Oluwafemi, O. O. (2017): 


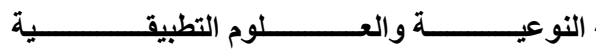
型

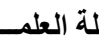

The Scientific Journal of Specific Education and Applied Sciences

Assessment of the Anti-Hyperglycaemic,Anti-Inflammatory and Antioxidant Activities of the Methanol Extract of Moringa Oleifera in Diabetes-Induced Nephrotoxic Male Wistar Rats. J. Molecules. 22: 439-455.

Enyioma, N. and Abdu A. (2005):

Update in diabetic nephropathy. Int. J. Diabetes \& Metabolism. 13: 1-9.

Fahey, J. (2005):

Moringa oleifera: a review of the medical evidence for its nutritional, therapeutic, and prophylactic properties, Trees Life J. 1:1-33.

Ghiridhari, W. A.; Malhati, D.; and Geetha, K. (2011): Anti-diabetic properties of drumstick (Moringa oleifera) leaf tablets. International Journal of Health and Nutrition. 2:1-5.

Govindarajan, K.; Aminu, U. K.; Palanisamy ,A.; Norhaszalina ,Md. and Sharida, F.(2016):

The modulatory effect of Moringa oleifera leaf extract on endogenous antioxidant systems and inflammatory markers in an acetaminophen-induced nephrotoxic mice model. PeerJ. 4: 2127-2160.

Guevara, A.P.; Vargas, C. and Sakurai, H. (1999):

An antitumor promoter from Moringa oleifera Lam. Mutat Res. 440(2):181-188.

Hakim, Z. S., Patel, B. K., Goyal, R. K. (1997) Effects of chronic

ramipril treatment in streptozotocin-induced diabetic rats. Indian

J. Physiol. Pharmacol. 41: 353-360

Hakim, Z. S.; Patel, B. K. and Goyal, R. K. (1997):

Effects of chronicramipril treatment in streptozotocininduced diabetic rats. Indian J. Physiol. Pharmacol. 41: 353360.

International Diabetes Federation, 2018: 


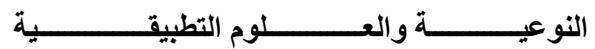
型

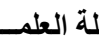

The Scientific Journal of Specific Education and Applied Sciences

Global prevalence of diabetes. International diabetes federation.

Jaiswal, D.; Rai, P.K.; Mehta, S.; Chatterji, S.; Shukla, S.; Rai, D.K.; Sharma, G.; Sharma, B. and Watal, G. (2013):

Role of Moringa oleifera in regulation of diabetes-induced oxidative stress. Asian Pac. J. Trop. Med. 6: 426-432.

Lako, J.; Trenerry, V. C.; Wahlqvist, M.; Wattanapenpaiboon, N.; Sotheeswaran, S. and Premier R. (2007):

Phytochemical flavonols, carotenoids and the antioxidant properties of a wide selection of Fijian fruit, vegetables and other readily available foods. Food Chemistry. 101(4):17271741.

Lalas, S. and Tsaknis, J. (2002):

Characterization of Moringa oleifera seed oil varietyPeriyakulam-1. J. Food Compos. Anal. 15: 65-77.

Marcela,V.J.; Manal, M. A. and Maria, L. F.(2017):

Bioactive components in Moringa Oleifera leaves protect against chronic disease. Antioxidants (Basel). 6(4): 91-100.

Mbikay,M. (2012):

Therapeutic potential of Moringa oleifera leaves in chronic hyperglycemia and dyslipidemia: a review, Front. Pharmacol. $3: 1-12$.

Muobarak, J. T. (2016):

Effects of Moringa oleifera aqueous leaf extract in alloxan induced diabetic mice. Interv Med Appl Sci. 8(3): 109-117.

Nadeem, M. and Imran, M. (2016):

Promising features of Moringa oleifera oil: recent updates and perspectives. Lipids Health Dis. 8; 15(1):212-227.

Olayaki, L.A; Irekpita, J.E; Yakubu, M.T. and Ojo, O.O. (2015):

Methanolic extract of Moringa oleifera leaves improves glucose tolerance, glycogen synthesis and lipid metabolism in 


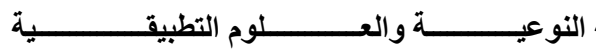
型

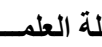

The Scientific Journal of Specific Education and Applied Sciences

alloxan induced diabetic rats. J. Basic Clin Physiol Pharmacol. 26(6): 585-93.

Philp, G. Reeves; Forrest, H. Nielsen and George, C. Fahey (1993):

AIN-93 Purified Diets for Laboratory Rodents: Final Report of the American Institute of Nutrition Ad Hoc Writing Committee on the Reformulation of the AIN-76A Rodent Diet. J. Nutr.123:1939-1951.

Pooja, A. S.; Madhuri, A. A.; and Ranjit, S.A. (2017):

Study of renal function and serum electrolyte in type $2 \mathrm{DM}$. International journal of innovative research in medical science. 2(8):2455-8737.

Prabhu, K.S.; Lobo, R. and Shirwaikar, A. (2008):

Antidiabetic properties of the alcoholic extract of Sphaeranthus indicus in streptozotocin-nicotinamide diabetic rats. J. Pharm Pharmacol. 60: 909-916.

Radhey, S. G. (2012):

Evaluation of antidiabetic and antioxidant activity of Moringa oleifera in experimental diabetes. Journal of Diabetes. 4 (2) 164-171.

Rajkumar, L.; Srinivasan, N.; Balasubramanian, K. and Govindarajulu, P. (1991):

Increased degradation of dermal collagen in diabetic rats. Indian J. Exp. Biol. 29: 1081-1083.

Rochette, L.; Zeller, M.; Cottin, Y. and Vergely, C. (2014):

Diabetes, oxidative stress and therapeutic strategies. Biochim Biophys Acta. 1840: 2709-2729. 


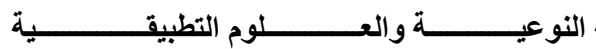
望

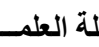

The Scientific Journal of Specific Education and Applied Sciences

Sanchez Machado, D.I. J.A.; Nunez Gastelum, D.I.; Reyes Moreno, C.; Ramirez Wong, B. and Lopez Cervantes, J. (2010):

Nutritional quality of edible parts of Moringa oleifera, Food Anal. Methods. 3: 175-180.

Santos, A.F.; Argolo, A.C.; Paiva, P.M. and Coelho, L.C. (2012):

Antioxidant activity of Moringa oleifera tissue extracts. Phytother Res. 26(9):1366-70.

Shenqi, W.; Xuhong, H. and Yu, L. (2013):

Serum electrolyte levels in relation to macrovascular complications in chinese patients with diabetes mellitus. Cardiovascular Diabetology.12 (146): 1-10.

Snehal, N. M.; Jayesh, B. D.; Sangita, B. K. and Archana, R. J. (2017):

Attenuation of diabetic nephropathy in streptozotocin-induced diabetic rats by Punica granatum Linn leaves extract. Journal of Traditional and Complementary Medicine, 7: 273-280.

Stohs, S.J. and Hartman, M.J. (2015):

Review of the safety and efficacy of Moringa oleifera. Phytother Res. 29(6):796-804.

Sunderman, F.W.JR. and Sunderman, F.W. 1958:

Serum electrolytes. A rapid, reliable method for serum potassium. Am. J. Clin. Pathol. 29(2): 95-103.

Sunny, O.A.; Sussan, B.; Sunday, G. E.; Godbless, O. and Goodluck, A. (2017):

Protective effect of Moringa oleifera oil against $\mathrm{HgCl} 2$ induced hepato- and nephro-toxicity in rats. J Basic Clin Physiol Pharmacol. 26; 28(4):337-345.

Szkudelski, T. (2001):

The mechanism of Alloxan and Streptozotocin action in B cells of the rat pancreas. Physiol. Res. 50: 536-546.

Tietz, N.W. (1994): 


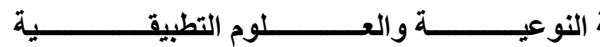

型

لالة العقد

The Scientific Journal of Specific Education and Applied Sciences

Fundamental of clinical chemistry. $2^{\text {nd }}$ ed. WB. Saunders, Philadelphia. 692-700.

Tietz, N.W. (1990):

Clinical guide to laboratory tests. $2^{\text {nd }}$ ed. WB. Saunders, Philadelphia. 566-574.

Tietz, N.W. (1986):

Textbook of clinical chemistry. WB. Saunders, Philadelphia.1271-1281.

Trinder, P. (1951):

A rapid method for sodium in serum. Analyst.76:596-599.

\section{World Health Organization (2016):}

Global report on diabetes. Geneva: World Health Organization.

Waller, R.A and Duncan, D.B. (1969):

A bays rule for the symmetric multiple comparison problem. Amer. State. Assoc. J. Dec., 1485-1503.

Yassa, H.D. and Tohamy, A.F. (2014):

Extract of Moringa oleifera leaves ameliorates streptozotocininduced Diabetes mellitus in adult rats. Acta Histochem. 116(5): 844-54. 


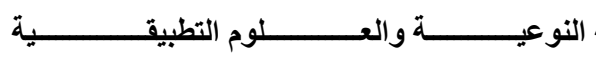
型

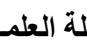
المج

The Scientific Journal of Specific Education and Applied Sciences

\section{تقييم التأثير الوقائي لزيت بذور المورينجا اوليفيرا

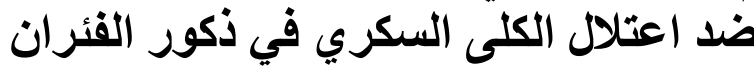

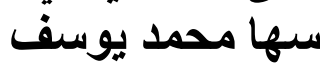

تخصص التغذية و علوم الأطعمة ـ قسم الاقتصاد المنزلي ـ كلية التربية النوعية ـ جامعة الفيوم -

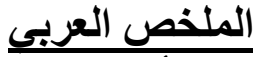

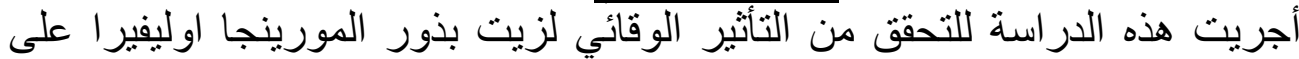

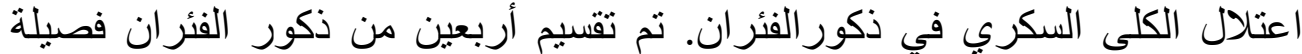

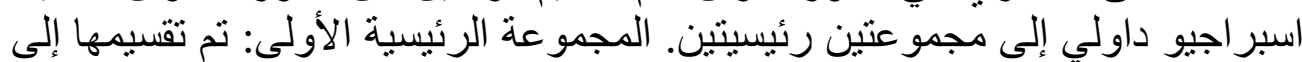

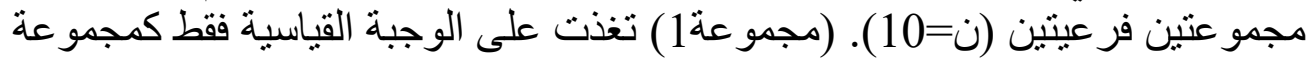

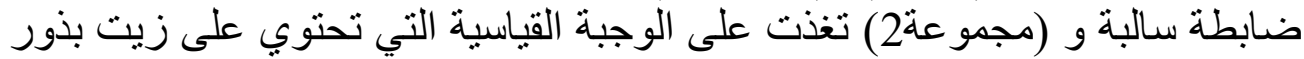

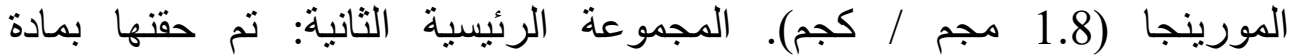

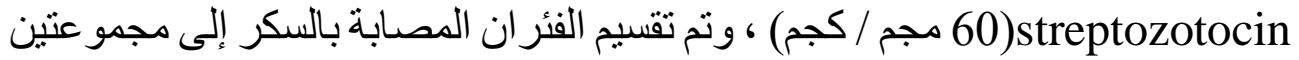

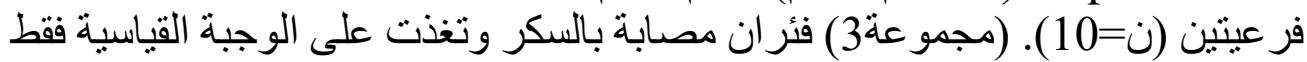

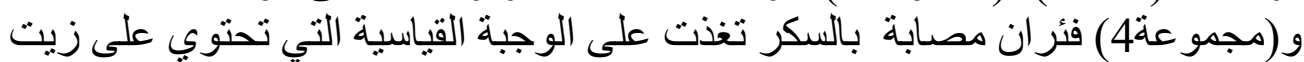

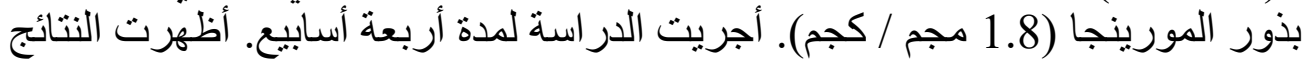

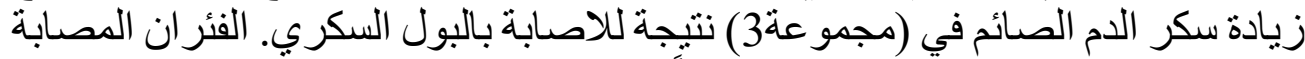

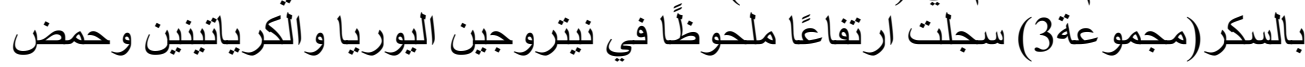

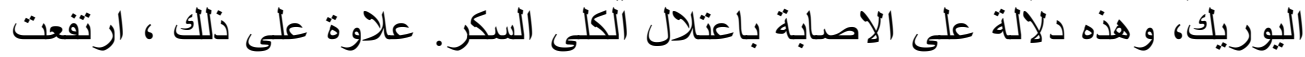

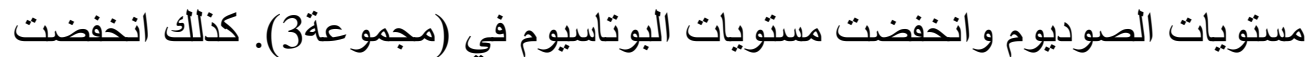

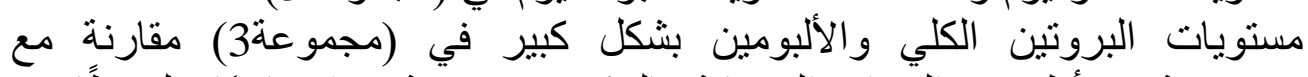

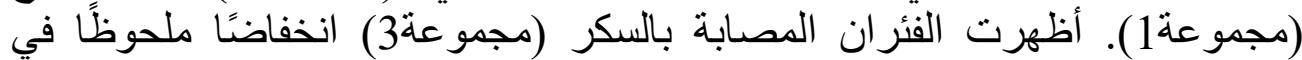

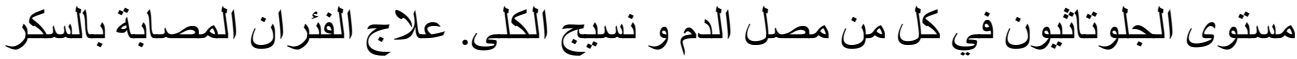

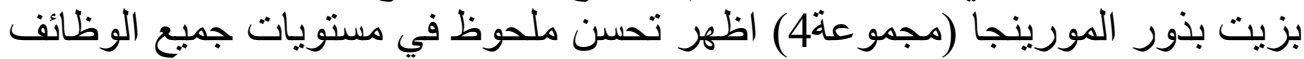

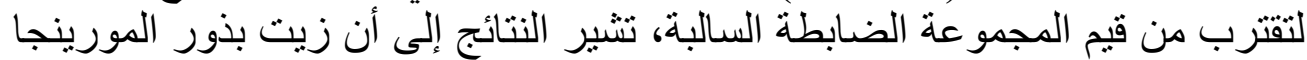

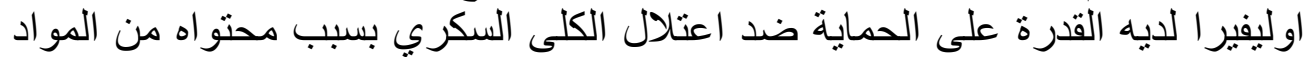

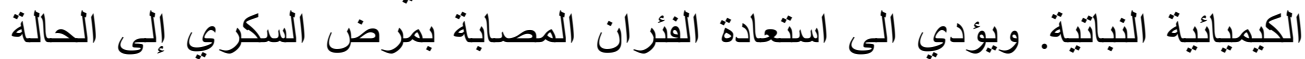
الصحية العادية. الكلمات المفتاحية: زيت بذور المورينجا ، اعتلال الكلى السكري، المواد الكيميائية النباتبة. 